\title{
Information and Communication Technologies as a Didactic Tool for the Construction of Meaningful Learning in the Area of Mathematics
}

\author{
Derling Jose Mendoza ${ }^{{ }^{*}}$, Derling Isaac Mendoza ${ }^{2}$ \\ ${ }^{1}$ Universidad Iberoamericana del Ecuador, ECUADOR \\ 2 Institute Giordano Bruno of Ecuador, ECUADOR \\ *CORRESPONDENCE: $\square$ derling969@gmail.com
}

\begin{abstract}
The main objective of the research is to analyze the cognitive attributes offered by Information and Communication Technologies to promote mathematical software as a model of teaching and learning. In the study, the software was used as a motivating didactic resource for the construction of meaningful learning. One hundred students of the first semester of Universidad Iberoamericana of Ecuador participated in this research. For the selection of the sample it was applied a nonprobabilistic participatory type technique. The study was developed according to the approach of mixed methods of sequential explanatory design. The researcher organized the article in two phases: the first phase was quantitative. Quantitative results were obtained by applying a questionnaire to the students. The data demonstrated the need for change in university mathematics education. For students in the first semester, it was implemented the Wiris and Geogebra operational program during the qualitative phase. Moreover, the observation guide made it possible to collect qualitative information. The results of both phases were joined through the triangulation method. In conclusion, it is proposed the use of software as a model of teachinglearning process. It is highlighted the importance of active group knowledge sharing.
\end{abstract}

Keywords: meaningful learning, mathematics teaching, information and communication technologies in education

\section{INTRODUCTION}

The Information and Communication Technologies (ICT) constitute an excellent didactic resource that is convenient to apply in class in order to make the most of the possibilities that they offer in the different areas and educational levels. It is necessary to face the task of incorporating ICT in order to update the contents and daily tasks for the development of the interest and motivation of students towards these resources, especially to improve teaching and learning processes.

The mathematics teaching-learning process at the universities, especially at Universidad Iberoamericana del Ecuador (UNIB.E) has become very complex lately, but it is a fundamental task, since it presents a fundamental basis in the curriculum of the degrees offered by this university. Therefore, mathematics teachers and other areas of science teachers are often confronted with changing and innovative teaching requirements, which require more attention from those engaged in research in the field of Arithmetic and especially in the planning of learning units to deal with the variety of subjects within and outside mathematics.

\footnotetext{
Article History: Received 10 August $2018 \bullet$ Revised 28 August $2018 \bullet$ Accepted 1 September 2018

(C) 2018 The Author(s). Open Access terms of the Creative Commons Attribution 4.0 International License (http://creativecommons.org/licenses/by/4.0/) apply. The license permits unrestricted use, distribution, and reproduction in any medium, on the condition that users give exact credit to the original author(s) and the source, provide a link to the Creative Commons license, and indicate if they made any changes.
} 
Moreover, the application of adequate and innovative resources and strategies, such as the introduction of ICT in mathematics activities, favors the flexibility of students' thinking because it stimulates the encounter of different solutions to the same problem. Besides, it allows a wider deployment of students' cognitive resources to facilitate the processes of meaningful learning building; that is the reason why it is important the study about promoting the use of ICT as a teaching tool. Moreover, it can be used as a motivating resource in teaching and learning activities in the mathematics area. It also allows giving feedback on the work through its use and facilitates the understanding of complex concepts and the development of cognitive skills, including several technology tools that can be used in the classroom.

According to this points of view, the research was focused on the analysis of the cognitive attributions provided by the use of ICT as a motivating didactic resource in the construction of meaningful learning in the mathematics area through the application of a series of phenomenological analysis to UNIB.E students.

\section{FRAMEWORK}

The objective of the article is to analyze the cognitive attributions generated by the use of ICT as a motivating didactic resource in the production of meaningful learning in the mathematics area by considering a computer as part of technological innovation which can be implemented as an alternative tool in the teaching and learning process. Therefore students can understand from a different perspective the applicability of this valuable tool in the development of educational activities. Furthermore, it provides a suitable environment for learning.

\section{Meaningful Learning}

The most important concept of Ausubel, (1976) is meaningful learning. This theory is based on previous knowledge because it is the support for the students to acquire and process new knowledge through the ability to relate it to the concepts they already have. Therefore, cognitive structure is the way in which the individual has organized pre-instructional knowledge. In this way, the theory of meaningful learning addresses each element, factor, condition and type that guarantee the acquisition, assimilation and retention of knowledge, so that it becomes meaningful for them.

It is evident that the origin of the theory of meaningful learning lies in the interest that Ausubel, (1976) has in knowing and explaining the conditions and properties of learning which can be related to effective and efficient ways to deliberately provoke stable cognitive changes, capable of providing individual and social meaning. As a consequence, what he wants to achieve is that learning that takes place in educational institutions is meaningful; this author understands that a learning theory that is realistic and scientifically viable must deal with the complex and meaningful character of verbal and symbolic learning. Likewise, and in order to achieve this meaningfulness, it must be paid attention to each element and factor that affect it, these ones can be manipulated for this purpose.

The Ausubelian Theory is a label that is very present in the dialogue between teachers, curriculum designers and educational researchers, but many are also unaware of its origin and justification. In relation to what was mentioned before, Coll and Solé, (2001) mention that the Ausubel's Theory refers to the possibility of establishing substantive and non-arbitrary links between what needs to be learned from the new content and what is already known and between what is found in the cognitive structure of the person learning based on his or her previous knowledge. According to this definition, meaningful learning means attributing meaning to the content that is being learned. Such attribution can only be made on the basis of what is already known, through the updating of knowledge frameworks relevant to the situation. These schemes are not limited to assimilating new information, but meaningful learning always implies its revision, modification and enrichment, establishing new connections and relationships between them, thus it ensures the functionality and comprehensive memorization of the contents learned significantly.

\section{Teaching Mathematics}

According to Pons, (2009) the best way for teaching-learning mathematics is to offer students all the benefits of the latest knowledge, technologies and procedures. The author highlights that technologies are alternative innovation resources that help students to improve their learning by successfully mastering content. As a result, it presents some characteristics as suggestions that should be developed in the classroom and outside it. Among these indications, it is emphasized that the objective in teaching mathematics should 
be that all students developed mathematical ability that is the processes understanding because recognizing that mathematical ability is a normal part of the mental skills of all individuals not just of a few students.

Therefore, it should be noted that the type of mathematics that focuses only on the algorithmic and mechanical are no longer interesting and useful after four or five weeks. Mora, (2002), emphasizes that the consolidation of mathematical knowledge is linked to the quality of the mathematical contents worked in the institution, the teaching strategies applied and most of all, the relationship between mathematics and reality. For this reason, it is very important to bear in mind that the success of teaching and learning depends not on the characteristics of the assessment itself, but even more on the didactic and andragogical work carried out in the classrooms. The more active, motivating and good teaching strategies during the learning and teaching process, the better the results obtained by assessing the students' mathematical knowledge.

\section{Technology in Education}

In the era of globalization, the use of technology is one of the most important applications in the field of education, which has allowed it to gain a legitimate place in the entire educational context in the world. Therefore, the use of technology in education has been a key to the development and creation of educational technologies in every day's life in university classrooms.

The implementation of new technologies has developed at the same time with the changes in teaching methods, according to Hernaiz (2006), which states that it is the student himself or herself who takes control of the process, materials and resources and adapts them to their requirements and possibilities according to the way of conceiving teaching-learning process.

This article is based on the Constitution of the Republic of Ecuador and the Organic Law of Intercultural Education of Ecuador (LOEI). Besides, the 1 $7^{\text {th }}$ article of the statute of the Ministry of Education states "To provide the highest authorities of public educational establishments with the use of authorized and standardized software and systems in the computer equipment of laboratories and administrative bodies of those establishments". This constitutional precept establishes the guarantee and services of ICT in universities.

As a result, teachers have found a world of possibilities for the development of their educational practice. These possibilities are found through the integration of new technologies as an additional resource in the teaching-learning process. This has allowed them to promote and facilitate the participative and creative attitude of the students, individualized teaching of interactive learning, distance learning and new methodologies such as computer-assisted teaching. This causes a real transformation in the teaching-learning process by giving the student a leading role.

Consequently, according to Area, (2005) technology in the educational field increases considerably, the amount of communication between the teacher and the students, regardless of the space and time they are in. The model of teaching through networks gives priority to the role of the teacher as a tutor of the student's academic work, rather than as a speaker of content. The author emphasizes that the combined use of human and material resources promotes more learning that is effective. The same applies to the application of techniques for the solution of educational problems.

In this context, Trejo (2005) mentions that it is important to provide students with computer-based problem-solving in mathematics as an applicable resource for students, parents and teachers, since technology seeks to erase this gap between unfounded efficiency and scientific knowledge by bridging the gap between technology and science. About this it can be concluded that educational technology, like mathematical didactics, deals with teaching practices. It also deals with the analysis between communication theory and new technological development for the development of thought from the interpersonal to the intrapersonal through the technological support (Yerizon \& Subhan, 2018).

The Wiris and GeoGebra programs were used as digital software to analyze cognitive influences on mathematics learning. The Wiris Mathematical Education Program is a software created by the company "Maths for More" and has a big presence in universities. Furthermore, it has the advantage that there is a lot of material which is designed and shared online. It has programs for calculation, arithmetic, statistics and algebraic hyperactivity (Calm et al., 2017). GeoGebra software is a free program designed for all levels of mathematics whose name combines Geometry and Algebra. Its design is represented by two windows. One for the geometrical interface in which the object or image is represented and the other for the algebraic interface in which the equations are expressed (Zengin, 2017). As described before, it can be concluded that educational 
technology, like mathematical didactics, deals with teaching practices, but unlike this, it includes among its concerns the analysis of communication theory and new technological developments.

\section{METHODOLOGY}

\section{Type of Study}

According to the stated objective, the research was carried out under the Multimethod or Mixed-method Approach defined by Hernández et al., (2014) as a set of systematic, empirical and critical research processes involving the collection and analysis of quantitative and qualitative data as well as their integration and joint discussion in order to draw inferences from all the information gathered (meta-conferences), again a better understanding of the phenomenon of study.

According to Hernández, (2017), The Sequential Explanatory Design Research (DEXPLIS) is characterized by a first stage in which quantitative data are collected and analyzed, followed by another stage in which qualitative data are collected and evaluated. Mixed mixing occurs when initial quantitative results inform qualitative data collection. It should be noted that the second phase builds on the results of the first phase. Finally, the findings of both stages are integrated into the interpretation and preparation of the study report. In the present study, it is given priority to qualitative results for the interpretation and explanation of findings in the conclusion.

\section{Sample of the Research}

The selection of the sample was of an intentional non-probability type. According to Otzen and Manterola (2017), this selection method allows the selection of a population by limiting the sample, it is used in scenarios where the population is very variable and consequently the sample is very small. In the case of the sample research, it was requested the participation of 100 students from the first semester of UNIB.E.

\section{Instruments and Information Analysis}

The first phase of research began with a quantitative study, using a questionnaire, defined by Casas et al., (2003) as a document that collects in an organized way the indicators of the variables involved in the objective of the survey. The survey technique, considered the most appropriate, was used to obtain information effectively from the student population, which was quantified by selecting students from the first semester of the production career. At the end of the data collection during the first week of the university semester, the data were organized and analyzed quantitatively, with the need to apply mainly the ICT at UNIB.E mathematics activities.

During the second research phase of the A-2018 semester (January - June), it was applied the current version of the Geogebra and Wiris Mathematics Operating Systems, which was developed in the network and computer labs of the university study. The general group of 100 students was divided into 4 sub-groups of 25 participants each one. The maths software activities were run on Monday, Tuesday, Thursday and Friday. Group 1 worked on Mondays from 9am to 10am. Group 2 worked on Tuesdays from 9am to 10am. Group 3 worked on Thursdays from 9am to 10am. Group 4 worked on Fridays from 9am to 10am (see Table 1).

Table 1. Distribution of population

\begin{tabular}{lcccc}
\hline Days & Monday & Tuesday & Thursday & Friday \\
\hline $\begin{array}{l}\text { Number of } \\
\text { students per group }\end{array}$ & Group 1 & Group 2 & Group 3 & Group 4 \\
$\begin{array}{l}\text { Time of weekly } \\
\text { activities }\end{array}$ & 25 students & 25 students & 25 students \\
\hline $\begin{array}{l}\text { Time of total } \\
\text { activities }\end{array}$ & \multicolumn{2}{|c}{1 hour } \\
\hline
\end{tabular}

In the weekly activities, an open and direct relationship was established between the researcher and the students when applying the technological equipment and software. Besides, it was reversed the adjacent relationship with the operating systems. During the second phase, the researcher applied the participant type observation guide as a key instrument for the collection of information. Landeau, (2012), when the researcher mixes with the situation observed and cooperates with the activities by identifying the aspects that interest them. The observation guide was a tool facilitated the collection and processing of qualitative data to develop 
an interpretive analysis by examining the phenomenon of interest sequentially and recording the data in the virtual environment.

For the analysis of the results of the research, the generalized triangulation of the results was carried out according to Donolo, (2009), as a control procedure implemented to ensure the reliability of the results of any research. Results that have been the subject of triangulation strategies may show more strength in their interpretation and construction than others that have been subjected to a single method.

The data obtained in the first phase, together with the qualitative information, were checked. The contrast or triangulation was performed with the theoretical adages of Ausubel which made easier an exhaustive and explanatory analysis of the results. Moreover, in order to highlight the important findings that emerged from the comparison, the inter-subjectivity of the study is considered a key segment in qualitative research. Besides, it is considered important to understand the educational meanings of ICT as a motivating educational resource for research.

\section{RESULTS AND DISCUSSION}

Below is the information collected according to the questionnaire applied to the students when the researcher had the opportunity to participate as an active member of UNIB.E. The purpose of the study in the first phase was to describe the mathematics teaching-learning process. Due to the sequential explanatory design, it was decided to open the quantitative analysis procedure that is understood as a deductive course of data in numerical form.

\section{Quantitative Phase}

The following table presents the data obtained by the questionnaire. The questionnaire was applied to the one hundred students of the first semester. Nine key questions of the study were highlighted. These had as answer choices the options, "totally agree" (TA), "agree" (A), "undecided" (U), "disagree" (D), "totally disagree" (TD) (See Table 1). These five options made it possible to quantify the results obtained in percentage terms (see Table 2).

Table 2. Questionnaire applied to students

\begin{tabular}{|c|c|c|c|c|c|c|c|c|c|c|c|c|}
\hline \multirow[t]{2}{*}{ N. ${ }^{o}$} & \multirow{2}{*}{\multicolumn{2}{|c|}{ Items }} & \multicolumn{2}{|c|}{$\begin{array}{l}\text { Totally } \\
\text { agree } \\
\text { (TA) }\end{array}$} & \multicolumn{2}{|c|}{ Agree (A) } & \multicolumn{2}{|c|}{$\begin{array}{l}\text { Undecided } \\
\text { (U) }\end{array}$} & \multicolumn{2}{|c|}{$\begin{array}{l}\text { Disagree } \\
\text { (D) }\end{array}$} & \multicolumn{2}{|c|}{$\begin{array}{l}\text { Totally } \\
\text { disagree } \\
\text { (TD) }\end{array}$} \\
\hline & & & FA & $\%$ & FA & $\%$ & FA & $\%$ & FA & $\%$ & FA & $\%$ \\
\hline \multirow{9}{*}{ 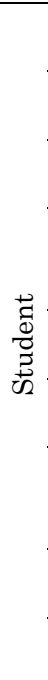 } & $\mathrm{s.1} \mathrm{I}$ & $\begin{array}{l}\text { If you use software for your maths activities, } \\
\text { do you feel like entering the classroom? }\end{array}$ & 50 & 50 & 40 & 40 & 10 & 10 & & & & \\
\hline & $\mathrm{s.2}$ & $\begin{array}{l}\text { Can you usewhat you learn in maths in } \\
\text { other subjects? }\end{array}$ & & & & & & & 80 & 80 & 20 & 20 \\
\hline & $\mathrm{s.3 \textrm {V }}$ & $\begin{array}{l}\text { Would you like to work in a group online } \\
\text { during the maths classes? }\end{array}$ & 80 & 80 & 20 & 20 & & & & & & \\
\hline & $\begin{aligned} \mathrm{V} \\
\mathrm{s} .4 \mathrm{n} \\
\mathrm{t}\end{aligned}$ & $\begin{array}{l}\text { When you have difficulties with } \\
\text { mathematics do you use the ICT to overcome } \\
\text { them? }\end{array}$ & 70 & 70 & 20 & 20 & 10 & 10 & & & & \\
\hline & $\mathrm{s.5} \mathrm{I}$ & $\begin{array}{l}\text { Do you think maths is interesting when you } \\
\text { see different problem-solving methods? }\end{array}$ & 60 & 60 & 40 & 40 & & & & & & \\
\hline & $\mathrm{s.6}$ & $\begin{array}{l}\text { When you use the computer do you feel } \\
\text { connected with your classmates? }\end{array}$ & 90 & 90 & 10 & 10 & & & & & & \\
\hline & $\begin{aligned} \mathrm{V} \\
\mathrm{s} .7 \mathrm{u} \\
\mathrm{g}\end{aligned}$ & $\begin{array}{l}\text { Would it make it easier for you to } \\
\text { understand the exercises when viewing the } \\
\text { graphical functions with the computer? }\end{array}$ & 40 & 40 & 60 & 60 & & & & & & \\
\hline & $\mathrm{s.8}$ & $\begin{array}{l}\text { Can maths assessments be performed } \\
\text { digitally? }\end{array}$ & 80 & 80 & 10 & 10 & 10 & 10 & & & & \\
\hline & $\mathrm{s.9}$ & $\begin{array}{l}\text { Are you excited that the teacher is updating } \\
\text { himself with the technology? }\end{array}$ & 80 & 80 & 20 & 20 & & & & & & \\
\hline
\end{tabular}

The results of the questionnaire applied to students were the following: According to question "s.1" the students showed a high percentage of optimism by indicating that they wanted to enter the classroom with the use of mathematical software. As shown in the same Table, $50 \%$ of the students responded that they totally agreed with what was described. The remaining $40 \%$, I agree with it. Finally, $10 \%$ of the students who responded were indecisive. Students today consider technological equipment to be an intellectual distraction 
in the context of their "status quo", contrary to the values weighted by the previous item in "s.2". The results show that their mathematics learning is not used in other subjects, being analyzed as a single or exclusive area which is isolated from the other areas in university education, with a weighting of $20 \%$ that totally disagrees completely and $80 \%$ disagrees. However, mastering this science facilitates how a human being can plan, organize and understand the environment from a rational perspective.

According to Qi, (2018) and Vilches and Gil (2005), cooperative work in the classroom appears to be an essential instrument for achieving meaningful learning and a growing interest in the subjects studied. Working in groups of three or four students generates energetic and productive activities, making it easier for the group to work in a suitable environment. Therefore, students who work alone are uncomfortable to build knowledge, they should always encourage the formation of groups in their activities. The teacher as the primary facilitator in the classroom derives from logic. If the grouping or subdivision of students is necessary. The question "s.3", 80\% of the adolescents indicated that they totally agreed to work in virtual groups in mathematics classes, as the remaining $20 \%$ did, they said they agreed with the results obtained in the questionnaire.

In management and research performance, professors may appreciate that when they join a research group, they can move on to the transmission of knowledge by reaching the same level as the rest of the team and can be compared to students in mathematics activities at the higher education level but not precisely with the application of alphanumeric language exercises by tackling problems in which they inform and participate in a heterogeneous way, interacting with proposals for the structuring of ideas. The results obtained by the groups in general can be reinforced. They may also be qualified by other teams, or by the student community.

It is remarkable that the results in "s.4" indicate that $70 \%$ are in full agreement with the use of ICT when they have difficulties with mathematics like the $20 \%$ of students who agree as well. This demonstrates the university's need to look for other methodologies and make meaningful changes in the process of teaching and learning. One of them is the implementation of ICT as a motivating and didactic tool. In this sense, it is important to affirm the need for the teacher and the student to assume. Zabalza (2005) says, that the term quality should always be applied to those institutions that have a diversity of resources. The following item "s.5" shows that students are interested in studying mathematics, especially when they see different study methods where the results obtained indicate that $60 \%$ of those surveyed are in complete agreement. As a consequence, you can see that the rest of the group agrees. Since the classes are no passive; that is they intervene voluntarily in the class. Its intervention is through different ways in the search for solutions or applications in mathematical activities.

After analyzing item "s.6", 90\% of students at the university reported full agreement on perceiving a virtual link when working with ICT, as well as $10 \%$ agreed. The dynamics of activity in the mathematics classroom eliminates the connotation of repetitive, boring and monotonous classes, to turn them into cognitively enriching research and creative groups, by increasing the interest of adolescents, they move forward collectively to the acquisition of the competencies investigated.

Cabero (2000) in addition to its possibilities for complementing and improving face-to-face teaching and learning processes, mentions that ICT makes it possible to create new on-line learning environments, which eliminates the need for teachers and students to coincide in space and time, all with the aim of providing new ways for research into the acquisition of new learning. Hence, the need to guide students in the management of educational programs aimed at developing mathematical content with the intention of strengthening the theoretical and practical knowledge of the subject. Virtual environments provide multiple junctures to support a student-centered mathematical model. ICT form a set of learning strategies that can be considered meaningful. In this way, the student adheres to an active and interactive standard in their training process. As indicated in point "s.7". of the questionnaire applied. Where $40 \%$ of young people are in complete agreement on understanding mathematical exercises more easily when it comes to visualizing the graphical functions on the computer. Adding the remaining $60 \%$ who agree.

On the other hand, the assessments made by mathematics teachers have always marked a high level of repudiation, rejection or phobia on the part of students. When they give activities in the traditional way, through handwritten exams with time limits recorded by the teacher (Legañoa et al., 2017). These techniques cause confusion and low concentration, unlike being displayed digitally by the student's monitor. Point "s.8" demonstrates the interest in applying a digitized mathematical assessment in a virtual environment. In most cases with $80 \%$ of students who agree completely. Adding up to $10 \%$ who agreed. 
The generation of students is now considered to be digital natives, as they were all born and raised using the particular "digital language" of computer games, video and the Internet (Prensky, 2010). This is how the digital natives are defined by the inevitable presence of ICT in today's society. Educational communities cannot isolate themselves from this environment, nor can teachers. According to the questionnaire in point "s.9", $80 \%$ of students are in complete agreement when they say they are enthusiastic. Just like your teacher who updates himself with technology. Adding up $20 \%$ of respondents who agree, as this way they can interact and think in the same way. Placing the teacher at the same level to which the teenagers are accustomed. Receiving data quickly and simultaneously, through images, graphics, videos and the Internet. The results of the questionnaire demonstrate the need to apply a mathematical model of meaningful teaching-learning.

\section{Qualitative Phase}

After completing the quantitative phase, it was fully demonstrated the need to apply operational mathematical software to students in the first semester. Qualitative data obtained from the observation guide were therefore collected and analyzed (see Table 3). These data are presented below:

Table 3. Observation guide applied to students

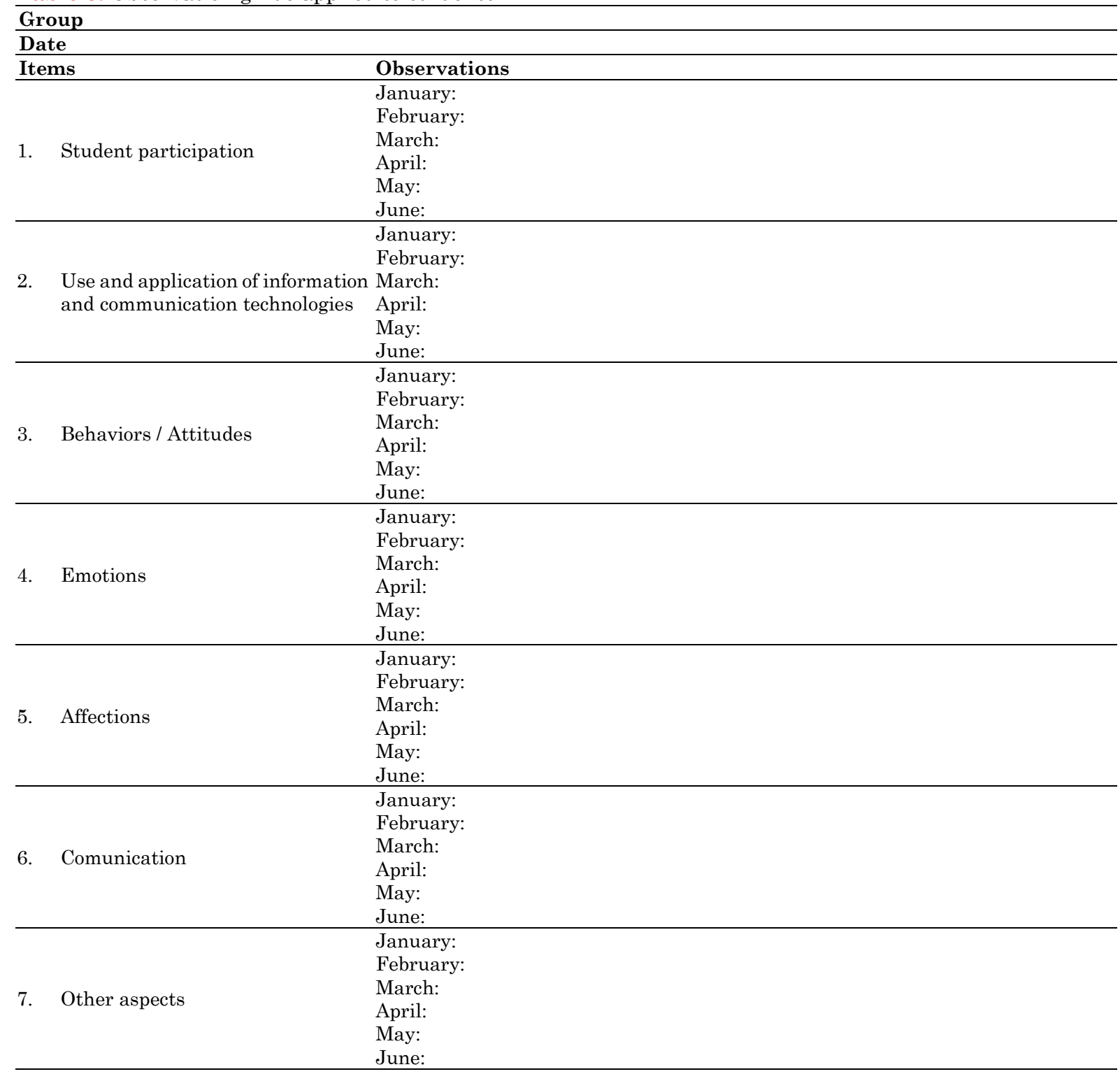

- It is noted that the use of ICT provides an environment of security, trust and empathy to express their knowledge and experiences freely. 
- The researcher observed that the students did not censor the questions or opinions. Questions were raised and support was offered in the search for solutions.

- The young people expressed in the study a great conviction that the learning took place in a warm, friendly and social environment. A climate of trust was also developed and it allowed them to participate naturally.

In relation to Items 1 and 2 of the observation guide, ICT allowed students to interact with the virtual classroom, as they are at a stage of physical development which took them to the same level of acquisition with a sense of primary trust, independence, initiative, motivation and achievement of numerical activities. Certainly, their biological and physical development has to do with emotions (Items 4) and existential anxieties according to Erikson's stages (Darling, 2018). The question of identity is naturally affected by these order somatic changes. The young people demonstrated their cognitive development in the search for information and manipulation by using the online digital connection as a mirror (Items 6). Biological changes cause such confusion that the students like to look frequently in the mirror to recognize themselves, show his own image and stabilize his learning.

As a cognitive attribute at this stage, it was successfully resolved that students should feel who they were and what they wanted by applying the use of ICT by gaining self-confidence (Items 3).

Moreover, identity represents an indispensable condition for the correct exercise of andragogic education. It was observed that the students faced tasks that consume a significant emotional burden on self-confidence. According to items 6, in distance maths activities, an open forum was maintained to maintain the educational discourse throughout the activities. This communication allowed the mutual knowledge, then it was the stage for the expression of results and motivations.

On the basis of Items 5 and 6 on affectivity and communication, a forum for the exchange of ideas was opened. Students would log in to discuss learning topics and at the same time, access the forum to post comments to their peers. On the other hand, the students expressed the affective need to generate study groups. The recording and application of virtual mathematical activities responds to a cognitive need, a personal need to be in communication with others to avoid isolation from the mathematical educational environment. This constant communication allowed us to socialize the experience, demonstrate and share the most complex numerical exercises. The presence of affectivity was available from informal to formal relationships which reduced the distance between peers. Enthusiasm for participation and interaction was provided on an ongoing basis, as all the students wanted to present ideas for exercise resolution.

Therefore, ICT should not necessarily be applied spontaneously, but the creation of intentional strategies and scenarios that benefit the group of learners is inspected. The use of GeoGebra and Wiris software as an educational model of teaching and learning was instilled as a didactic resource for the construction of meaningful learning. Through inter-communication, it was proved that the software promotes emotional bonds that allow the formation of an intellectual, open and high stimulation mathematical environment (García \& Romero, 2018). Among other aspects, according to Item 7, virtual mathematical problems created cognitive conflicts that guided the group of students in their search for results. In the search for results, opinions were given through the recovery of past experiences. It was possible to perceive that the students understand the geometric formulations, through images and graphics. After understanding geometry through Geogebra is constructed a significant thought by applying the Wiris for systematic and empirical solutions of calculation.

In the applied activities it was observed a cognitive interaction that allows to highlight a process of construction of mathematical knowledge. These interactions focused on critical thinking, with statements about the triggering of events as the starting point for discussions, such as questions, doubts, problems and statements for the investigation of ideas, concepts, axioms and solutions to the proposed exercises (Martínez, 2017). It was evident the educational value between technology and mathematics as a model. Students expressed that learning mathematics was a social process and not an individual one. In addition, the large dimension of mathematical problems faced by adolescents in their daily lives was resolved through group research (Azorín, 2018). Therefore, it is necessary for the maths classroom to be a setting for online citizenship learning.

The technique of group learning also generated an action that contributed to the construction of virtual thinking according to Vargas \& Villalobos, (2018). Most of the complex exercises required the skill of the participants. During the problems that arose in the context of the mathematical activities, it was offered the opportunity to choose the mathematical exercises to be solved. It was very convenient for the students to be 
able to choose the exercises and to design action plans to address them. There were also discussed the desirability and feasibility of the planned operations. Moreover, everything was developed with teamwork, asked by the students because they considered it, more comfortable. The group study model allowed significant progress in logical mathematical reasoning through online communication with other students.

Among the main results it can be argued that:

- The use of ICT provides an environment of security, trust and empathy to freely express their knowledge and experiences.

- Students did not censor questions or opinions. Questions were raised and support was offered in the search for solutions.

- The mathematical software in group generates a great conviction that the learning is formed in a warm, friendly and social environment. It also develops a climate of trust that allows for natural participation.

\section{CONCLUSIONS}

In conclusion, it can be deduced in a visionary way that university students are the future rulers of society. Considering the dynamic nature of knowledge, it is clear why it is necessary to interpret and understand the different attributes that students perceive when teaching mathematics today. In relation to the demands, that tomorrow's scientific and technological environment will make it will be more effective for them to perceive information. The effectiveness of ICT is not only conceived for its usefulness for confirmed and technical training.

However, there are unique reasons for this discipline that justify its teaching for the cognitive development of students. In fact, it has been shown that professionals take mathematics as a profession and not as a vocation which leaves serious consequences that cognitively influence mathematical thinking. According to Mendoza and Flores, (2018) in Ecuador, not all teachers are prepared for mathematics education; the learning model has much to do with the way in which it is taught. Hence, the way in which the process of teaching and learning mathematics at different levels is carried out, is a factor of great impact in the relation that students will have with this subject in the future Arcavi (2018).

On the other hand, it can be said that in Latin America the teaching population in mathematics has always been low (Martínez et al., 2017). Therefore, it is not necessary to address the teaching of this subject as if in the future all students were mathematics teachers. It is also necessary to determine how to teach it, so that it will favors the integral formation of the citizen of the future. Therefore, those who facilitate mathematics at the higher education level, have a great impact on the relation between their students and this area in the future (Matas \& Quispe, 2014).

Considering this observation, it is stated that mathematics teachers have two options. One is to consider it as a science made, in which nothing can be modified. And secondly, to see it as a science to be projected. It is possible to reinvent what is distinguished by those who master mathematics, but it is not yet dominated by those who are trying to learn it. It should be added that the students expressed that by applying the mathematical software, they had enough time, as mentioned by Ríos et al. (2016). On the contrary to Herrera, (2018), teachers who have less time to work in a virtual environment with students.

To sum up:

- One of the main aspects of the application of ICT in university mathematics education is the appreciation of the student as a constructor of meaningful learning and a developer of his or her own cognitive level adjusted to his or her own mathematical instruction. This implies that students should be offered spaces of freedom in their relationship and digital connectivity with the mathematical processes that must be appropriated to develop their academic training.

- Any university mathematics teacher may decide to invent, innovate or test new approaches to teaching arithmetic or elementary geometry, especially if it takes into account the negative results that traditional teaching has produced.

- ICT produces big changes, both in the contents to be taught and in the practices that the mathematics teacher puts into play in the virtual classrooms. Thus, these attributions, which the students admit, lead them to obtain a better mathematical performance and it stops certain anomalies described by Novelo et al. (2014) as boredom, beliefs and negative conceptions that society has established about this science, which has generated in young people the phobia or mathematical aversion. These anomalies 
were overcome by introducing a new model of learning based on digital practice, giving student's responsibility for their own learning, under face-to-face and distance learning, but with the supervision of research professors.

\section{Disclosure statement}

No potential conflict of interest was reported by the authors.

\section{Notes on contributors}

Derling Jose Mendoza - Universidad Iberoamericana del Ecuador, Ecuador.

Derling Isaac Mendoza - Institute Giordano Bruno of Ecuador, Ecuador.

\section{REFERENCES}

Arcavi, A. (2018). Towards an Integrative Vision of the Teaching and Learning of Mathematics. Education Mathematical, 30(2), 33-48. https://doi.org/10.24844/EM3002.02

Area, M. (2005). De las Bibliotecas Universitarias a los Centros de recursos para el Aprendizaje y la Investigación. Madrid: CRUE.

Ausubel, D. (1976). Psicología educativa. Un punto de vista cognoscitivo. México: Trillas.

Azorín, C. (2018). El método de aprendizaje cooperativo y su aplicación en las aulas. Perfiles Educativos, 40(161), 181-194

Cabero, J. (2000). Nuevas tecnologías, comunicación y educación. Universidad Nacional Abierta. Venezuela: Edutec.

Calm, R., Masía, R., Olivé, C., Parés, N., Pozo, F., Ripoll, J., \& Sancho, T. (2017). Use of wiris quizzes in an online calculus course. Journal of Technology and Science Education, 7(2), 221-230. https://doi.org/10.3926/jotse.253

Casas, J., Repullo, J., \& Donado, J. (2003). La encuesta como técnica de investigación. Elaboración de cuestionarios y tratamiento estadístico de los datos (I). Atención Primaria; 31(8), 527-38.

Coll, C., \& Solé, I. (2001). Aprendizaje Significativo y Ayuda Pedagógica. Revista Candidu, 15, 1-21.

Constitution of the Republic of Ecuador (1999).

Darling, C. (2018). Application of the Modified Erikson Psychosocial Stage Inventory: 25 Years in Review. Western Journal of Nursing Research, O(0), 0193945918770457. https://oi.org/10.1177/0193945918770457

Donolo, D. (2009). Triangulación: procedimiento incorporado a nuevas metodologías de investigación. Revista Digital Universitària, 10(8), 5-24.

García, G., \& Romero, J. (2018). Math for All in Times of Inclusion as an Imperative: A Study on the Program Todos a Aprender. Revista Colombiana de Educación, 74, 289-310.

Hernaiz, J. (2006). Aprender a valorar la matemática. Medellín: Limusa.

Hernández, R. (2017). Fundamentos de Investigación. México: Mc GrawHill.

Hernández, R., Fernández, C., \& Baptista, P. (2014). Metodología de la investigación. México: Mc GrawHill.

Herrera, M., Fernández, D., \& Seguel, R. (2018). Teachers' perception about ICT integration in teaching practices in relation to the normative frameworks for the teaching profession in Chile. Ensaio: Avaliação e Políticas Públicas em Educação, 26(98), 163-184. https://doi.org/10.1590/s010440362017002501119

Landeau, R. (2012). Metodología y nuevas tecnologías. Caracas: Alfa.

Legañoa, M., Báez, I., \& García, J. (2017). Attitude toward mathematics: teachers' capacity to consider them. Transformación, 13(1), 56-65.

Martínez, D. (2017). Critical thinking assessment in education for citizenship. Proposal for overcrowded Contexts. Didacticae, 3, 131-144. 
Martínez, M., Araya, P., \& Berger, B. (2017). Descripción del cambio del profesor de matemática desde su propia perspectiva a partir de una experiencia en torno a resolución de problemas de final abierto. Bolema: Boletim de Educação Matemática, 31(59), 984-1004. https://doi.org/10.1590/19804415v31n59a07

Matas, A., \& Quispe, W. (2014). Evaluación de las "competencias docentes" en maestros de matemáticas de Puno (Perú) Profesorado. Revista de Currículum y Formación de Profesorado, 18(1), 257-278.

Mendoza, D., \& Flores, E. (2018). Relación entre el rendimiento académico de los estudiantes universitarios en el área de matemática y la praxis docente mediadora. INNOVA Research Journal, 3(6), 21-31.

Ministry of Education (2012). Ministerial agreement. Agreement Number 0357-12.

Mora, C. (2002). Estrategias para el Aprendizaje y la Enseñanza de la Matemática. (Doctoral dissertation). Universidad Central de Venezuela, Caracas.

Novelo, S., Herrera, S., Díaz, J., \& Salinas, H. (2014). Fear of math: cause and effect. Revista Iberoamericana de Producción Académica y Gestión Educativa, 2, 1-15.

Organic Law of Intercultural Education. Ecuador, (2012).

Otzen, T., \& Manterola, C. (2017). Sampling Techniques on a Population Study. International Journal Morphology, 35(1), 227-232.

Pons, W. (2009). La Tecnología Educativa. Argentina: Magisterio del Rio.

Prensky, M. (2010). Nativos e Inmigrantes Digitales. España: SEK.

Qi, Z. (2018). Personalized Distance Education System Based on Data Mining. International Journal of Emerging Technologies in Learning (IJET), 13(07), 4-16. https://doi.org/10.3991/ijet.v13i07.8810

Ríos, A., Londoño, F., \& Yañez, J. (2016). ICT competency and its relationship with the skills for solving problems of mathematics. Edutec. Revista Electrónica de Tecnología Educativa, 57, 17-32. https://doi.org/10.21556/edutec.2016.57.760

Trejo, R. (2005). Diseño de Actividades Educativas Apoyadas en la Tecnología de la Informática. Madrid: Grado.

Vargas, A., \& Villalobos, G. (2018). The use and impact of virtual platforms in the learning process: experience with students of criminology and police science at Universidad Estatal a Distancia Costa Rica. Educare Electronic Journal, 22(1), 1-20. https://doi.org/10.15359/ree.22-1.2

Vilches, A., \& Gil, D. (2005). El trabajo cooperativo en el aula: una estrategia considerada imprescindible pero infrautilizada. Revista de la Universitat de València, 208, 41-46.

Yerizon, A., \& Subhan, M. (2018). Mathematics Learning Instructional Development based on Discovery Learning for Students with Intrapersonal and Interpersonal Intelligence (Preliminary Research Stage). International Electronic Journal of Mathematics Education, 13(3), 97-101. https://doi.org/10.12973/iejme/2701

Zabalza. (2005). Investigación Cualitativa, Retos e Interrogantes. Madrid: La Muralla

Zengin, Y. (2017). The effects of GeoGebra software on pre-service mathematics teachers' attitudes and views toward proof and proving. International Journal of Mathematical Education in Science and Technology, 48(7), 1002-1022. https://doi.org/10.1080/0020739X.2017.1298855 